\title{
Combination of photodynamic therapy and phototherapy for the treatment of cutaneous open wounds in dogs - case reports
}

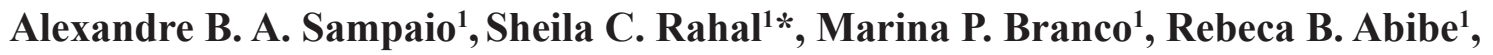 \\ Henrique O. Dorth' ${ }^{1}$, Jeniffer G. F. Coris ${ }^{1}$, and Luciana Almeida-Lopes ${ }^{2}$ \\ ${ }^{1}$ Department of Veterinary Surgery and Anesthesiology, School of Veterinary Medicine and Animal Science, \\ Botucatu, SP, Brazil \\ ${ }^{2}$ Research and Education Center for Photo Therapy in Health Sciences - NUPEN, São Carlos, SP, Brazil
}

SAMPAIO, A. B. A., S. C. RAHAL, M. P. BRANCO, R. B. ABIBE, H. O. DORTH, J. G. F. CORIS, L. ALMEIDA-LOPES: Combination of photodynamic therapy and phototherapy for the treatment of cutaneous open wounds in dogs - case reports. Vet. arhiv 91, 559-564, 2021.

\section{ABSTRACT}

The evolution of cutaneous open wounds was evaluated in five client-owned dogs treated with photodynamic therapy (PDT), mediated by methylene blue and phototherapy with light-emitting diodes (LED) as the light source. On the first day of treatment, the wound was irrigated with sterile $0.9 \%$ sodium chloride solution, the surface was dried, and 3\% solution of hydrogen peroxide soaked for 1 minute. The hydrogen peroxide was mechanically removed and, immediately after, $0.01 \%$ methylene blue was used in the wound for five minutes, after which a cluster of red LEDs (650 - $670 \mathrm{~nm}$ wavelength, $350 \mathrm{~mW}$ power, and irradiance of $200 \mathrm{~mW} / \mathrm{cm} 2$ ) was used. Subsequently, single phototherapy sessions, every 48 hours or more, were applied until wound healing. In general, 24J was used for PDT and 12J for phototherapy. In all cases, the cutaneous open wounds treated with PDT associated with phototherapy healed without complications, and it may be considered as a treatment option, especially for extensive lesions.

Key words: healing; photodynamic therapy; light-emitting diode; wound

\section{Introduction}

Photodynamic therapy (PDT) and phototherapy are light-based therapeutic modalities that have been used, alone or in combination, in the treatment of cutaneous wounds with promising results (TARDIVO and BAPTISTA, 2012; SAMPAIO and LOPES, 2015).

In PDT, the photosensitizers from different groups, such as porphyrins, chlorophylls or dyes, are activated by exposure to light, and convert light energy into Type 1 and Type 2 chemical reactions

(ALLISON et al., 2004; PEPLOW et al., 2012; KIKUCHI et al., 2015). In a Type I reaction, the light energy progresses from excited triplet molecules to biomolecules, which leads to direct damage to the biomolecules, or causes the formation of reactive oxygen species (TARDIVO and BAPTISTA, 2012). In a Type 2 reaction, the triplet-state energy of the photosensitizer is transferred to molecular oxygen, resulting in singlet oxygen generation, which is capable of damaging membranes, proteins and

\footnotetext{
*Corresponding author:

Sheila C. Rahal, PhD, MSc, DVM, School of Veterinary Medicine and Animal Science - São Paulo State University (UNESP), Botucatu, SP, Rubião Júnior s/n, 18618970, Brazil, Phone: +55 143880 2041; E-mail: sheila.canevese-rahal@unesp.br
} 
DNA (DAI et al., 2009; TARDIVO and BAPTISTA, 2012; FU et al., 2013). If the cells to be eradicated are considered pathogenic microorganisms, the procedure is known as photodynamic inactivation (DAI et al., 2009).

PDT has the potential to eliminate or kill pathogens in the infected tissue without causing resistance induction; however, the antimicrobial effect ceases when the light is turned off (DAI et al., 2009). The light penetration and photosensitizer action may be affected by the presence of thick pus and devitalized tissue; therefore, pus drainage, debridement and washing of the wound must be done to increase the effectiveness of PDT (JERJES et al., 2012). In addition, because of structural differences in bacterial cell walls, there are also differences in the effectiveness of the various photosensitizers regarding Gram positive or Gram negative bacteria (FU et al., 2013).

Regarding phototherapy, light-emitting diode (LED) studies showed an increase in cell growth in vitro, for example in mouse-derived fibroblasts and normal human epithelial cells, and in vivo wound healing time decreased in crew members aboard a submarine (WHELAN et al., 2001). LED phototherapy with combined 660 and $890 \mathrm{~nm}$ lights promoted healing of diabetic ulcers in human patients that had been subject to other treatments without success (MINATEL et al., 2009).

A few reports have used a combination of these therapeutic modalities in small animals (SAMPAIO and LOPES, 2015). Therefore, the aim of the current case reports was to evaluate the evolution of cutaneous open wounds in dogs treated with PDT mediated by methylene blue, and phototherapy with LEDs as the light source.

\section{Case presentation}

This study was approved by the Ethics Committee for the Use of Animals of the School of Veterinary Medicine and Animal Science (CEUA - No. 44/2016). Only client-owned dogs with cutaneous open wounds that had experienced any untoward complications involved in the wound-healing process were included. Patients were excluded from the study if they had an open wound presenting within 24 hours of injury. Data regarding the dog's signalment (breed, gender, age, body mass), and relative to the wounds (cause, time of occurrence, and previous treatment) were analyzed. Protocols were determined depending on the severity of the cutaneous wounds. In general, on the first day of treatment the hair was clipped around the wound site, the wound was irrigated with sterile $0.9 \%$ sodium chloride solution $(50 \mathrm{~mL}$ syringe attached to an 18 gauge plastic catheter), the surface was dried, and soaked in a $3 \%$ solution of hydrogen peroxide for 1 minute. The hydrogen peroxide was removed mechanically and, immediately after, $0.01 \%$ methylene blue (Blumet, DMC, SC) was used as a photosensitizer in the wound for five minutes, after which the cluster of red LEDs was used. Subsequently, single sessions were applied every 48 hours or more, in the event of the unavailability of the dog's owner, until wound healing. The red LEDs (Vet Light, DMC, SC) had 650-670 nm wavelength, $350 \mathrm{~mW}$ power, and irradiance of $200 \mathrm{~mW} / \mathrm{cm} 2$. The distance between the LED light source and the wound was approximately 5 $\mathrm{cm}$. In general, 24J was used for PDT, and 12J for phototherapy. After each session, vaseline ointment (Vaselina, Uniphar, GO) was applied to the wound, which was covered with a rayon dressing, or the wound was left without dressing. Vaseline ointment was used solely to avoid adherence of the rayon dressing to the wound. The wounds were cleansed using a normal saline solution. PDT was used again when signs of wound infection were observed. Tramadol chlorhydrate (Cronidor; Agener União, São Paulo), at a dose of 2-4 mg/kg, PO, q12h, and dipyrone (Dipirona; Biovet, São Paulo), at a dose of $25 \mathrm{mg} / \mathrm{kg}$, PO, q8h, were prescribed for pain relief. Photographic documentation of the cutaneous wound healing was made.

Case 1 was a 12-year-old crossbred female dog, weighing $7.7 \mathrm{~kg}$. The dog was referred due to dehiscence of two traumatic wounds, presented after approximately 28 days. One wound was also related to possible pharmacodermia. According to the owner, the wounds had been treated with nitrofurazone ointment, and the dog had received ceftriaxone and metronidazole. The dog had also been submitted to tibiotarsal arthrodesis 
surgery two days earlier to be examined by us and enrofloxacin had been prescribed for 7 days. Physical examination revealed one wound located in the left inguinal region and the lateral region of the thigh, and the other on the left lumbosacral region. The wounds were considered infected due to purulent discharge, necrosis areas and skin loss. In addition, laboratory tests showed that the dog had chronic kidney disease. The treatment included 13 sessions: 1 session of PDT, and 12 sessions of LEDs (12J). Vaseline ointment was used. The wounds were healed by 38 days (Fig. 1).
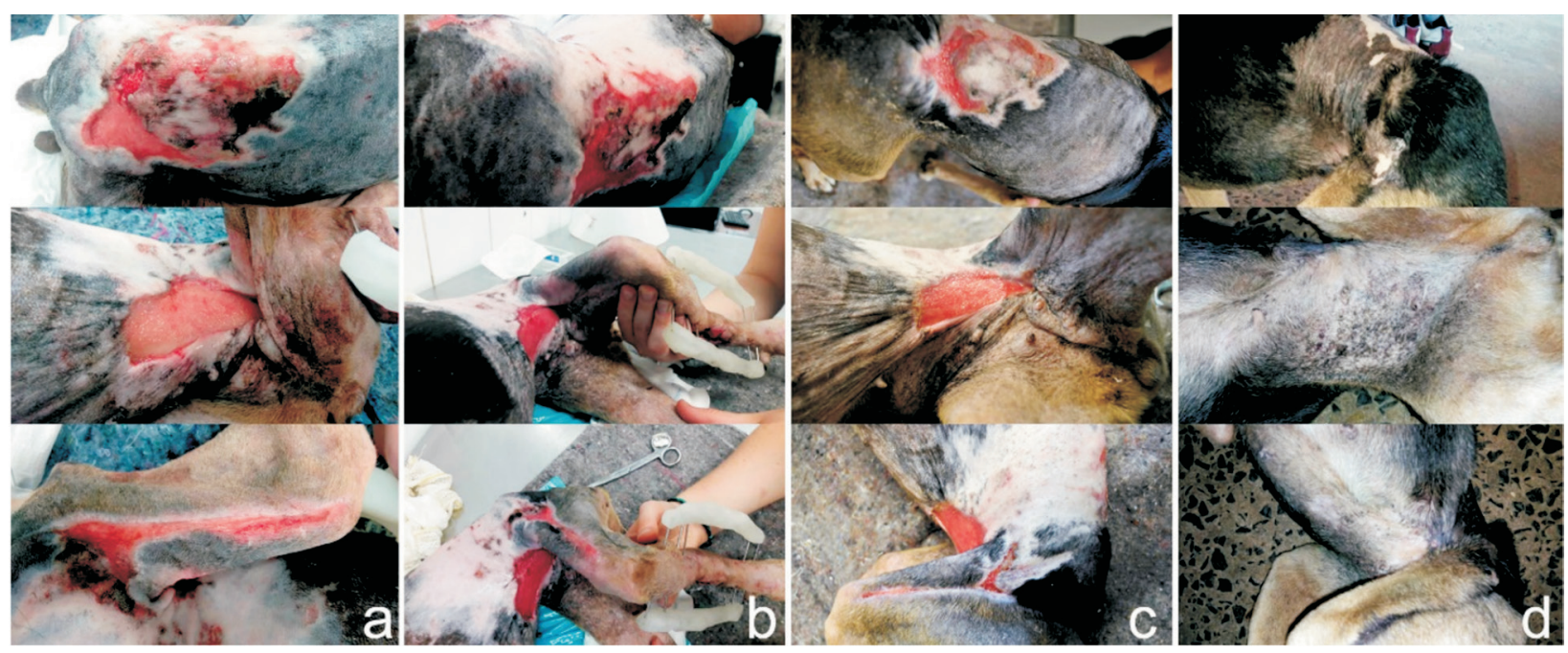

Fig. 1. Dog 1 with the presence of cutaneous wounds in the left lumbosacral region (possible pharmacodermia), and the left inguinal region and lateral region of the thigh (traumatic wounds). Before photodynamic therapy (a), on day 4 (b) and day 11 (c) of the phototherapy treatment with LEDs, final appearance (d) at 2 months after completion of therapy.

Case 2 was a 1.5-year-old, $13-\mathrm{kg}$, female Australian Cattle Dog that was presented because of a traumatic wound due to neurological complication after a right femur fracture. Wound age was 45 days. According to the owner, the previous wound treatment was irrigation with chlorhexidine or povidone-iodine, and topical rifamycin. The region of the right third and fourth digits had an ulcerated lesion with irregular borders and pale in color. The treatment included 24 sessions: 1 session of PDT, and 23 sessions of LEDs (24J in 3 initial sessions and $12 \mathrm{~J}$ for the others). No wound dressing was used. The wound was healed by 84 days (Fig. 2).
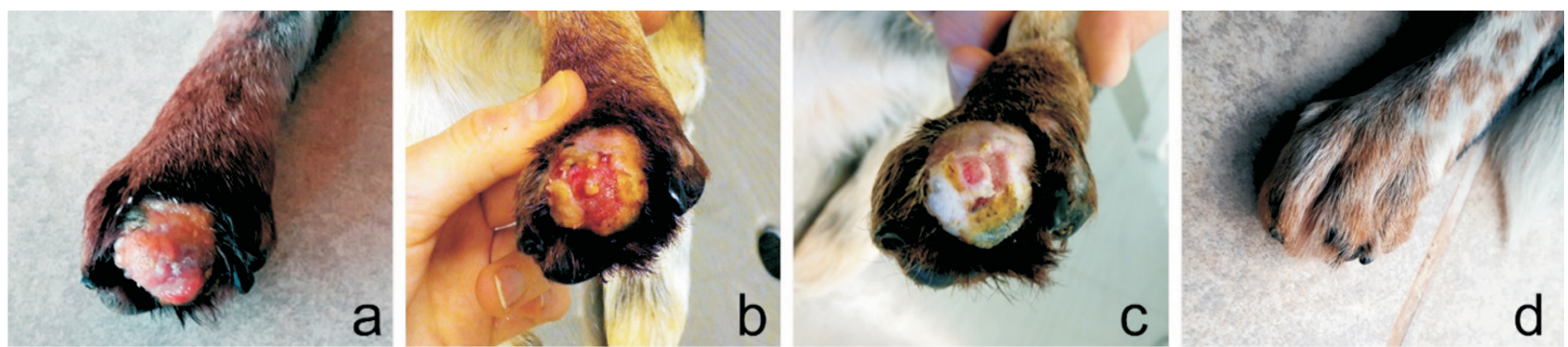

Fig. 2. Dog 2 with a wound located in the region of the right third and fourth digits. Before the photodynamic therapy (a), on day 21 (b) and day 39 (c) of the phototherapy treatment with LEDs. (d) Final appearance at 1 month after completion of therapy. 
The case 3 was a 1-year-old male Yorkshire Terrier, weighing $1.4 \mathrm{~kg}$. A contaminated wound with skin loss located on the latero-cranial region of the left metatarsus and left digits was observed. The skin wound was presented after 48 hours and the cause was unknown trauma. The dog had also a fracture of the right tibia that was treated surgically. For this, he received amoxicillin-clavulanic acid for 7 days. The wound treatment included 17 sessions: 1 session of PDT, and 16 sessions of LEDs (12J). Vaseline ointment was used. The wound was healed by 22 days.

Case 4 was a 4-year-old, 5-kg, male Brazilian Terrier that was referred due to a wound located in the middle third of the radius and ulna as a result of a bite 10 days previously. According to the owner, the wound had been treated with collagenase ointment, but the dog was constantly licking it. The wound was considered to be contaminated. The wound treatment included 3 sessions: 1 session of PDT, and 2 sessions of LEDs (12J every 5 days). After 1 week of therapy, the dog stopped licking the wound. No wound dressing was used. The wound was healed by 15 days.

Case 5 was a 7-year-old male Pitbull, weighing $35 \mathrm{~kg}$. The dog was referred due to partial dehiscence of a traumatic wound presented approximately 7 days previously. According to the owner, the dog had received cephalexin. Physical examination revealed an infected wound located in the left lateral thoracic region that exhibited purulent drainage at the dehiscence site (gaping). The wound treatment included 6 sessions: 2 sessions of PDT, and 4 sessions of LEDs (12J every 3 days). No wound dressing was used. The wound was healed by 20 days.

\section{Discussion}

In the present report cases, methylene bluemediated PDT was used for LED irradiation. The photodynamic reaction is dependent on the presence of a sufficient amount of photosensitizer, administered topically or systemically, which needs to be selective for the target tissue (MORTON et al., 2008; JERJES et al., 2012). Of the azine dye photosensitizers, methylene blue is classified as a phenothiazine dye targeting lysosomes (PEPLOW et al., 2012; KIKUCHI et al., 2015). It is considered an efficient and inexpensive option for topical use (TARDIVO and BAPTISTA, 2012), which was one of the reasons for using it in these cases.

Circular wounds in mice that were treated with methylene blue-mediated PDT (laser) showed that the photosensitizer was not detrimental to wound healing, since no delay in wound healing was observed compared to the control group (SPERANDIO et al., 2010). On the other hand, in 2-mm diameter wounds of the rat buccal mucosa, the PDT using low-intensity laser and photosensitizer methylene blue caused an inhibitory effect on the healing process on day 14, despite the fact that, on previous days, neutral or accelerating effects had been observed (DEYHIMI et al., 2016). Since PDT was used in our cases, especially at the beginning of the treatment, no inhibitory effect could be proven. On the other hand, amelioration of the infection was noticed following its use. The same was observed in a dog with a large and infected open wound that was treated using methylene blue as the photosensitizing dye and low-intensity laser irradiation (SAMPAIO and LOPES, 2015). In addition, this type of therapy may be useful in animals with systemic diseases, in which antibiotic drugs should be avoided. One example is dog 1 that suffered from chronic kidney disease and received antibiotics due to tibiotarsal arthrodesis, but continued the wound treatment without it.

In addition, pre-treatment by soaking the wound with hydrogen peroxide for 1 minute before the application of methylene blue was used to enhance PDT efficiency against microorganisms. Some in vitro studies have shown that the combination of methylene blue and hydrogen peroxide has enabled a better action against bacteria as well as fungi, probably due to the increase in reactive oxygen species formation inside the microorganism (GARCEZ et al., 2011; GARCEZ and HAMBLIN, 2017). Swabs and culture of the wounds could not be taken due to the socio-economic status of the owners, and this may be considered a limitation. However, the wounds classified as infected had purulent discharge and devitalized tissue.

There are several light sources that can be used in PDT and/or phototherapy, including lasers, filtered 
xenon arc, fluorescent lamps and LEDs (WHELAN et al., 2001; BAROLET, 2008; MORTON et al., 2008; SAMPAIO and LOPES, 2015). In the present cases, red LEDs were used. Light sources that are not laser have advantages such as easy use, stable, less expensive, low-maintenance and the field of illumination provided is wide (MORTON et al., 2008). Wide-field illumination was important in dogs 1 and 3 that had large area wounds, since the equipment had irradiance of 6 LEDs with $130 \mathrm{~mW} /$ $\mathrm{cm}^{2}$. The biological effects of LEDs depend on parameters such as dose, intensity, irradiation time, continuous wave or pulsed mode, and pulse patterns (WHELAN et al., 2001; BAROLET, 2008).

The dosage of $12 \mathrm{~J}$ was used the most during treatment. The equipment of LEDs used in the present study were manufactured for providing energy doses of $12 \mathrm{~J}$ and $24 \mathrm{~J}$, with a fixed exposure time, which makes the procedures easier. In addition, the equipment has red light and a wavelength of 650-670 $\mathrm{nm}$, which was considered suitable for the size and depth of the wounds treated in the present study. The wavelength of the LEDs should permit the adequate penetration of light into the target cells or tissue; red light can be utilized for deeper targets and blue light for treatment of skin conditions located in the epidermis (BAROLET, 2008). In addition, LED wavelengths of 680,730 and $880 \mathrm{~nm}$ are considered most suitable to speed wound healing (WHELAN et al., 2001).

In conclusion, the cutaneous open wounds treated with PDT associated with phototherapy healed without complications in all cases. This combination may be considered as a treatment option, especially for extensive lesions.

\section{References}

ALLISON, R. R., G. H. DOWNIE, R. CUENCA, X. H. HU, C. J. CHILDS, C. H. SIBATA (2004): Photosensitizers in clinical PDT. Photodiagnosis Photodyn. Ther. 1, 27-42.

DOI: 10.1016/S1572-1000(04)00007-9

BAROLET, D. (2008): Light-emitting diodes (LEDs) in dermatology. Semin. Cutan. Med. Surg. 27, 227-238. DOI: 10.1016/j.sder.2008.08.003

DAI, T., Y-Y. HUANG, M. R. HAMBLIN (2009): Photodynamic therapy for localized infections - state of the art. Photodiagnosis Photodyn. Ther. 6, 170-188.

DOI: $10.1016 /$ j.pdpdt.2009.10.008
DEYHIMI, P., H. KHADEMI, R. BIRANG, M. AKHOONDZADEH (2016): Histological evaluation of wound healing process after photodynamic therapy of rat oral mucosal ulcer. J. Dent. (Shiraz) 17, 43-48.

FU, X-J, Y. FANG, M. YAO (2013): Antimicrobial photodynamic therapy for methicillin-resistant Staphylococcus aureus infection. BioMed. Res. Int. 2013, 1-9.

DOI: $10.1155 / 2013 / 159157$

GARCEZ, A. S., S. C. NÚÑEZ, M. S. BAPTISTA, N. A. DAGHASTANLI, R. ITRI, M. R. HAMBLIN, M. S. RIBEIRO (2011): Antimicrobial mechanisms behind photodynamic effect in the presence of hydrogen peroxide. Photochem Photobiol Sci. 10, 483-490.

DOI: $10.1039 / \mathrm{c} 0 \mathrm{pp} 00082 \mathrm{e}$

GARCEZ, A. S., M. R. HAMBLIN (2017): Methylene blue and hydrogen peroxide for photodynamic inactivation in root canal - a new protocol for use in endodontic. Eur Endod J. 2, 1-16.

DOI: $10.5152 /$ eej.2017.17023

JERJES, W., H. B. TAN, C. HOPPER, P. V. GIANNOUDIS (2012): Surgical site infections subjected to photodynamic therapy: a potential application in orthopaedic surgery. Hard Tissue. 10, 1-8.

KIKUCHI, T., M. MOGI, I. OKABE, K. OKADA, H. GOTO, Y. SASAKI, T. FUJIMURA, M. FUKUDA, A. MITANI: Adjunctive application of antimicrobial photodynamic therapy in nonsurgical periodontal treatment: a review of literature. Int. J. Mol. Sci. 16, 24111-24126.

DOI: $10.3390 /$ ijms 161024111

MINATEL, D. G., M. A. C. FRADE, S. C. FRANÇA, C. S. ENWEMEKA (2009): Photototherapy promotes healing of chronic diabetic leg ulcers that failed to respond to other therapies. Lasers Surg. Med. 41, 433-441.

DOI: $10.1002 / 1 \mathrm{sm} .20789$

MORTON, C. A., K. E. McKENNA, L. E. RHODES (2008): Guidelines for topical photodynamic therapy: update. Br. J. Dermatol. 159, 1245-1266.

DOI: $10.1111 / \mathrm{j} .1365-2133.2008 .08882 . \mathrm{X}$

PEPLOW, P. V., T. Y. CHUNG, G. D. BAXTER (2012): Photodynamic modulation of wound healing: a review of human and animal studies. Photomed. Laser Surg. 30, 118148.

DOI: $10.1089 /$ pho. 2011.3142

SAMPAIO, A. B. A., L. A. LOPES (2015): Association between phototherapy and photodinamic therapy in the treatment of dog skin wound. Medvep. 12, 1-5.

SPERANDIO, F. F., A. SIMÕES, A. C. ARANHA, L. CORREA, S. C. O. MACHADO DE SOUSA (2010): Photodynamic therapy mediated by methylene blue dye in wound healing. Photomed. Laser Surg. 28, 581-587.

DOI: $10.1089 /$ pho.2009.2601 
TARDIVO, J. P., M. S. BAPTISTA (2012): Photodynamic therapy in the treatment of osteomyelitis. In: Osteomyelitis (Baptista, M. S., Ed.), InTech, pp. 121-130.

WHELAN, H. T., R. L. Jr. SMITS, E. V. BUCHMAN, N. T. WHELAN, S. G. TURNER, D. A. MARGOLIS, V. CEVENINI, H. STINSON, R. IGNATIUS, T. MARTIN, J. CWIKLINSKI, A. F. PHILIPPI, W. R. GRAF, B. HODGSON, L. GOULD, M. KANE, G. CHEN, J. CAVINESS (2001): Effect of NASA light-emitting diode irradiation on wound healing. J. Clin. Laser Med. Surg. 19, 305-314.

DOI: $10.1089 / 104454701753342758$
Received: 7 December 2019

Accepted: 26 June 2021

SAMPAIO, A. B. A., S. C. RAHAL, M. P. BRANCO, R. B. ABIBE, H. O. DORTH, J. G. F. CORIS, L. ALMEIDA-LOPES: Kombinacija fotodinamičke terapije i fototerapije u liječenju otvorenih kožnih rana pasa - prikazi slučajeva. Vet. arhiv 91, 559-564, 2021.

\section{SAŽETAK}

U istraživanje je uključeno pet pasa s poznatim vlasništvom kod kojih je procijenjeno cijeljenje otvorenih kožnih rana. Psi su liječeni fotodinamičkom terapijom (PDT) uz primjenu metilnog modrila i fototerapijom uz primjenu svjetlećih dioda (LED) kao izvora svjetla. Prvi dan pokusa rana je tretirana sterilnom 0,9\%-tnom otopinom natrijeva klorida, njezina je površina posušena te je tijekom jedne minute vlažena $3 \%$-tnom otopinom hidrogen-peroksida. Odmah potom hidrogen-peroksid mehanički je uklonjen, zatim je tijekom pet minuta upotrijebljeno $0,01 \%$-tno metilno modrilo, a nakon toga više povezanih crvenih LED dioda (valne dužine $650-670 \mathrm{~nm}$, snage $350 \mathrm{~mW}$ i zračenja $200 \mathrm{~mW} / \mathrm{cm} 2$ ). Poslije toga primijenjena je fototerapija, svakih 48 sati ili u duljem intervalu, sve dok rane nisu zacijelile. Primijenjeno je $24 \mathrm{~J}$ za PDT i 12 J za fototerapiju. U svim su slučajevima otvorene kožne rane, koje su liječene kombinacijom PDT-a i fototerapije, zacijelile su bez komplikacija. Navedeno otvara mogućnosti primjene ovih metoda, posebice na ranama s velikim lezijama.

Ključne riječi: cijeljenje; fotodinamička terapija; svjetleće diode; rana 